\title{
Political Marketing Communication Strategy of Prabowo-Sandiaga in the 2019 Presidential Elections
}

\author{
Ellaine Bingarrayni ${ }^{1}$, Nur Kholisoh ${ }^{2}$ \\ \{el.0909@yahoo.com¹, nur.kholisoh@mercubuana.ac.id ${ }^{2}$ \} \\ Universitas Mercu Buana, Jakarta, Indonesia ${ }^{12}$
}

\begin{abstract}
Political marketing holds an important role in democratic context which is actualized by marketing strategies as the best method to gain a triumph. In addition, the candidates must convince the voters to take sides and vote for them. This can be achieved if the candidates obtain a great support from the voters. This situation is relevant to Prabowo-Sandiaga as one of the candidates in the 2019 presidential elections. In politics, neuroscience approach can be applied as one of the strategies for political marketing. A research on neuroscience is important to carry out in order to inform the ongoing situation to society and enable them to respond and also take sides for controversial statements delivered by the candidates in their campaigns. This research aimed to study the political marketing strategy conducted by PrabowoSandiaga on social media in order to obtain a support in the 2019 presidential elections. This research applied a symbolic interaction theory and political marketing communication which are categorized as a method and marketing applications in politics. The paradigm used in this study was constructivists with case study method and deep interview as the data collection techniques. The interviewees were individuals who involved in the campaign team of Prabowo-Sandi, social media account administrators of Prabowo-Sandi, several political communication experts, and neuroscientists. The results revealed that Prabowo-Sandi applied a Lees-Marshment method as the political marketing communication strategy with economic populist program as the political product offered to constituents.
\end{abstract}

Keywords: Political Marketing Communication, symbolic interaction, social media, and neuroscience

\section{Introduction}

In the political situation that is full of open competition and transparency, candidates need a method to communicate their political initiatives, political ideas, political issues, party ideology, and party or candidate work programs to society. Therefore, it requires a strategy to succeed the political competition, including by communicating the right political marketing. The term "Political marketing" includes these activities made by political parties to affect voters and is focused on influencing the individuals regarding political candidates to reach the maximum number of votes [1]. Political marketing communication can also be implemented to build brand awareness among young voters [2]. In the 2019 presidential election, political marketing held an important role in democratic context which is actualized by marketing strategies as the best method to gain a triumph [3]. 
Marketing, adapted in politics, can also be applied to increase the efficiency and effectivity for ideological transfer and work programs from candidates to society. Marketing has been expanded into politics with its development in business over the years. In politics, marketing strategies are used to communicate with the voters nowadays. Political marketing is evolving and campaigns now rely on political marketing for success in elections [4], [5]. Marketing can also inspire the candidates in creating products in the form of issues and work programs based on problems being faced by society.

Meanwhile, the research [6] found that political marketing has attracted the attention of political actors in recent years in Albania. The importance of political marketing makes political actors not only act, but also to think in terms of marketing. One of the marketing instruments that political parties use to reach the voters is the magic of social media [1], [7]. Media holds a great contribution in building public opinion, thus society is interested to follow the ongoing issues. Based on a series of in-depth interviews with key politicians, campaigners, social media and media users, Saraswati et al. [8] found that there is involvement of the political campaign industry in the commodification of social media.

New media as the means of conveying messages in mass communication is used by individual or group, including political party. The digital revolution has dramatically changed the conventional system of political representation and media, contributing to cultural changes in the public sphere that require a different conceptualization of the social mediation process. [9]. In the meantime, many political parties are using new media, such as internet as the communication political platform. The current social media landscape has two key aspects to it. First are the platforms and Second are the use cases [10]. According to Neilsen, in the second quarter of 2015, Indonesia ranked the 8th out of 3.2 billion internet users in the world (Internetworldstats, 2015 in [11]). As stated by APJJI, 87,13\% of youngsters access Facebook, Instagram, Twitter, and YouTube.

Meanwhile, neuroscience approach can be applied as one of the political strategies in political marketing. Neuroscientists have begun to investigate whether different political attitudes are associated with specific mind-brain markers [12]. The results of Kanai et al. [13] research found that political attitudes reflect differences in self-regulatory conflict monitoring and recognition of emotional faces by showing that such attitudes are reflected in human brain structure. In politics, neuroscience approach is known as neuro politics. In the 2019 presidential election, there were two pairs of candidates named Petahana and Penantang. As being observed in the political narratives during the campaign period, the Petahana led by Joko Widodo often stated his achievements during his time as a president in the former period. While the competitor, Prabowo-Sandiaga revealed problems that occur in Indonesia and offered solutions to tackle them. The political narratives delivered by the two candidates became a hot issue if media wrote publications with varied ideologies and point of views

A research on neuroscience is important to carry out in order to inform the ongoing situation to society and enable them to respond and also take sides for controversial statements delivered by the candidates in their campaigns. Research by Svetlik [14] show that voters perceive this form of advertising as one that offers them more information, attract a greater degree of attention and more trust than in the case of positive advertising. Meanwhile, Hamelin et al. [15] found that a mere 60 seconds was enough to heighten the participant emotional state and significantly alter participant perception and ratings about these politicians.

Therefore, this research aimed to study the political marketing strategy conducted by Prabowo-Sandiaga on social media in order to obtain a support in the 2019 presidential 
election. At the same time, for the contestant and political parties, this research intended to give references to understand the right political marketing communication strategy in order to gain a support.

\subsection{Literature Review}

\subsubsection{Symbolic Interaction Theory}

The symbolic interaction theory assumes that a meaning is created through interaction and being modified via interpretation. The way of how people interact each other is based on the meaning given by another individual. The effective communication will not happen unless a meaning is uttered. We are easily communicating with those who share the same language with us compared to those who do not. According to Herbert Blumer [16], there are three assumptions of this theory: (1) people act based on a meaning conveyed to them; (2) a meaning is created in human interaction; (3) a meaning is modified through interpretation.

\subsubsection{Political Marketing Communication}

The word strategy is generated from "strategia" coming from Greek which means "the art of general" or the art of a commander in a war [17]. In the meantime, the word strategy is no longer limited to the war field, but it has been widely used including in communication science and also political science. In a broad meaning, strategy is the way to gain victory or accomplish a goal, including in politics. Shama [18] in Ormrod et al. [19] defines political marketing as the process by which political candidates and their ideas are aimed at voters to meet their potential needs and thus gain their support. One of the political marketing models which is widely used in these recent days is Lees-Marshment Model. This model is also known as Comprehensive Political Marketing (CPM) model [20]. This focuses on what a party does in order to respond society needs. There are characteristics of CPM model, namely: applying marketing approach to the entire political organizations, integrating political science in the political analysis and concept that is used to adjust traditional knowledge of the political party; and highlighting Product Oriented Party (POP), Sales Oriented Party (SOP), and Market Oriented Party (MOP).

\begin{tabular}{|c|c|c|}
\hline $\begin{array}{l}\text { Product Oriented } \\
\text { Party (POP) }\end{array}$ & $\begin{array}{l}\text { Sales Oriented Party } \\
\text { (SOP) }\end{array}$ & $\begin{array}{l}\text { Market Oriented } \\
\text { Party (MOP) }\end{array}$ \\
\hline $\begin{array}{l}\text { Oriented on } \\
\text { products. Party or } \\
\text { candidate already } \\
\text { has products } \\
\text { (regulations, } \\
\text { candidates, work } \\
\text { programs, etc.) and } \\
\text { promote their } \\
\text { products in order to } \\
\text { convince the voters. }\end{array}$ & $\begin{array}{l}\text { Oriented on selling. } \\
\text { Party or candidate } \\
\text { already has } \\
\text { products. However, } \\
\text { in order to adjust } \\
\text { with the voters } \\
\text { needs, the products } \\
\text { can be adjusted. }\end{array}$ & $\begin{array}{l}\text { - Oriented on market. } \\
\text { Products of party or } \\
\text { candidate } \\
\text { (regulations, } \\
\text { candidates, work } \\
\text { programs, etc.) are } \\
\text { adjusted or created } \\
\text { based on the voters } \\
\text { needs. }\end{array}$ \\
\hline
\end{tabular}

Fig 1. Lees-Marshment Model

\subsubsection{Neuroscience}

Neuroscience studies consciousness and brain sensitivity seen from biological aspect, perception, memory, and its relation to learning. The nervous system and brain are the physical principles for the human learning process. Ikrar [21] explains that this discipline has a wide application starting from marketing (neuromarketing), computer (neuro-simulation), cognitive behavior (neuropsychology), and politics (neuropolitics). According to William 
Connolly [22], the combination presents roles in thinking, ethics, and politics. By conducting his research on nervous system to explore how brain activity is affected by cultural conditions and stimuli such as film techniques, Connolly is able to form a new perspective on negotiation and its improvement in a highly pluralistic society where culture and economics continue to improve.

Paul D. Maclean's [23] Triune Brain Theory originated from his hypothesis in the 1960s, an American Neuroscientist who explained the evolution of the vertebrate brain in his book The Triune Brain in Evolution. Based on this theory, the human brain is divided into three parts, namely the Reptilian Complex or also known as the Croc brain or crocodile brain, or lizard brain, or old brain, or lower brain, or primitive brain in our brain stem, often known as brainstem. Next, the second is the Mammalian Brain or Limbic System (Limbic system) which is the emotional brain in the middle, and the third is NeoCortex or human brain, rational brain.

\subsubsection{Campaign}

A campaign is a doctrinal act aimed at obtaining support. It can be carried out individually or in an organized group to achieve a decision. In addition, a campaign can also be done to influence, inhibit, and divert achievement. Meanwhile, according to Imawan (in Cangara [24] a campaign is a persuasive attempt to invite people who are not in line or not sure about ones' ideas, so later they are willing to join and support them. Referring back to those definitions, each campaign activists must contain at least four requirements, namely: the campaign is aimed to create certain effects or impacts, it contains a large number of audiences, it is focused in a certain period of time, and it requires a series of organized communication actions.

\subsubsection{Social Media as a New Media}

A term of new media has been used since 1960s and has reached a developed and diversified set of applied communication technologies [25]. New media can be defined as "a series of broad changes to media production, media distribution, and media use" [8], [26]. Nowadays, internet as a new means of communication, becomes a need for many people because it offers fast access in sending or receiving data, provide information from anyplace, and help people to communicate each other despite the fact that they live in different area. A set of internet-based application which is manufactured based on ideology and technology Web 2.0 that is possible to create or switch user-generated content by Andreas Kaplan dan Michael Haenlein [27] is called social media. According to Feri Sulianta [28], there are types of social media, namely: Facebook, Twitter, YouTube, and Instagram.

\section{Research Method}

This research applied constructive paradigm in the form of qualitative research. This approach enables the researcher to understand what is hidden behind a phenomenon which is usually complicated to recognize or comprehend. The analysis method used in this research was neuroscience approach. The data collection was carried out by means of unstructured interview, non-participant observation by monitoring contents in the official account of Prabowo-Sandiaga and studying some documents and achieves which were related to the research problems. 
The interviewees were individuals who involved in the campaign team of PrabowoSandi, social media account administrators of Prabowo-Sandi, several political communication experts, and neuroscientists. The data analysis was conducted by applying Miles and Huberman model in which the qualitative data analysis was done interactively and continuously until the data became saturated. The analysis was done by data reduction, data display, and drawing a conclusion [29]. This research used data validity techniques by triangulating data sources by checking the data that had been obtained through several data sources, namely interviews, observations and literature reviews.

\section{Results and Discussion}

The research results reveal that Prabowo-Sandi applied Sales Oriented Party approach where it belongs to one of Lees-Marshment political marketing communication models. It can be observed through steps carried out by the team campaign of Prabowo-Sandi in marketing political products offered to society. In the beginning, Prabowo-Sandi formed their political products in the form of vision, mission, and other related ideas by solving economic problems, namely: creating the greatest possible job opportunities, stabilizing the price of basic commodities, and optimizing Indonesia's natural wealth for the benefit of the society. This was stated by Kawendra Lukistian as follows:

Pak Prabowo and Bang Sandi have the main message. The main idea is about the economy, how to create the greatest possible job opportunities, how to stabilize prices and basic commodities, and optimize Indonesia's natural wealth to be explored as much as possible by the Indonesian people.

The political product is in line with clauses in Article 33 of the 1945 Constitution of the Republic of Indonesia which emphasizes on economic populist. The same thing was stated by Mardani Ali Sera, who was one of the political campaign staffs of Prabowo-Sandi:

Bang Sandi wins the positioning aspect ... a solution for the Indonesian economy but the way to wrap it up ... the segmentation is young people, young style, and that's why if you look at Sandi, Sandi rarely wears formal clothes. The style of young people are always like that.

According to Mardani, since in the beginning, Prabowo-Sandi offered some programs focusing on economic populist, but specifically for Sandi, it was more aimed at the segmentation of young people who were categorized as the swing voters and had great potential in the 2019 election. As stated by Kawendra, the efforts done by political campaign staffs of Prabowo-Sandi to grab the intention of swing voters were deemed successful since the political narratives focused on economic field, as disclosed in the following interview:

yeah..um..the swing voters during the last presidential election were quite a lot. We put in quite an extraordinary effort to grab swing voters' attention and it turned out, and it turned out, all swing voters were concerned almost with the economic narrative. In our survey, there was always updated data so we map everything, what was the process, we had to visit any point, all by data. It's almost all economic narratives and most of the swing voters, it's millennials, and millennials like the original, authentic and what it was, and didn't like conflict ..

The interview expressed by Kawendra is not only presenting the offered programs, but also present the second step done by political campaign staffs of Prabowo-Sandi named market research. Based on the interviews, it signifies Prabowo-Sandi did not stop at making programs but also followed up with market research to find out to what extent the programs 
offered were accepted by constituents, especially among young people. A different statement spoken by Mardani signifies that market research which was done to measure the offered program implementation was deemed not effective so that the results were not satisfying as stated in the following interview:

So, both (product design and market research) were carried out, market research ... but to be honest... I was not very satisfied; the current market was different from ... for example in Jakarta. While in Jakarta we held two FGDs. The first FGD found the key problem, it was flood and traffic jam, yes, but when we threw flood and traffic jam problems into our discussion, it turned out that they didn't have any conversations, no conversations, no, no, no ... there was no feedback. Finally, we made the second FGD, we discussed OK OCE (One Center of Entrepreneurship). It turned out that when we explored it, I also saw that the FGD was alive. In a full day, three segments, society, house wives, e .. workers, and young people, we all meet, the most important thing was not traffic jams and floods but economy, economy, economy, that's why OK OCE came out.

The interview expressed by Mardani Ali Sera signifies the difference input of market research. This is definitely influencing the steps which was done in the third year, namely communicating political messages based on market research which had been done the year before. According to Mardani, restating the messages is important in order to embed the messages to society. This strategy, as said by Mardani, is not done by Prabowo but carried out by Sandi. The statement is stated as follows:

So, if the Prabowo-Sandi, in my opinion, yes ... because I do not have full control, the answer is the same, e... like this, in the public sphere especially during the campaign period, don't think the public is spoiling a candidate, there must be one 'strong message 'which is repeated and always referred to if there is one, it is the derivative of the message, but actually it's still there. Now that's what Pak Prabowo does not do. If Sandi is right, if you look at friends ... Sandi's answers, Sandi's questions are always, that's why in young people, we grab their attention. What is the Sandi's answer? Um .. employment, employment, employment, economy, economy, economy. That's why the perception of "brand image" on the job field, especially if we have a Rumah Siap Kerja, all kinds of things, we can do that. So um ... for Pak Prabowo, I think he cannot make it, but Sandi yes.

The strong message on economic aspect, especially those which are related to job opportunity provision, was deemed successful to draw young people attention. This message was also conveyed in the fourth phase, when the direct and indirect campaign were conducted in mass media. Firman Kurniawan, a communication expert of Universitas Indonesia found an interesting point about message campaigned through social media. According to Firman, it had been a noticeable segregation between the two candidates (Prabowo-Sandi dan Jokowi-Ma'ruf) in almost social media. This statement is uttered as follows:

Actually, on Instagram and YouTube, it is the same ... the same ... so ... if you look at the position of the supporters is really polarized and the contribution of polarization is driven by any social media. So, when Mr. Prabowo has his haters on Twitter, the lovers also try to keep up. Likewise, when on Instagram, Mr. Prabowo has a lot of lovers, the next camp also builds haters. Now, if we look at the situation, there is really "segregation", there is a noticeable separation between the two candidates, and it applies to all mediums that I observe.

The noticeable separation between the two candidates was continuously take place until the election day was held. The difference was the messages delivered to the constituents. 
Prabowo-Sandi still kept up to deliver messages related to economic populist as stated by Kawendra:

Characteristically, the excellence of Pak Prabowo and Bang Sandi during the last presidential election was consistent, our narrative was consistent. Almost all of our narratives were mostly about the economy, about the fate of the people, and our narratives were natural.

The consistency on the populist economy program is kept conducted by the campaign team of Prabowo-Sandi even though they failed on the election. It was executed in the form of a program which was directly implemented to society by establishing Rumah Siap Kerja (sociopreneur platform). This statement is stated as follows:

Well, and ... and ... thank God, currently Prabowo Sandi did not win, we do not have a good fortune in the last presidential elections, but until now, Sandi, Prabowo, Pak Prabowo joined Pak Jokowi's government to remain the best minister. This means that the capacity is indeed capable and Sandi even though ... Sandi, me and other friends who are still outside the government are consistent in building the economy, in what ways? by keep supervising OK OCE and running the Rumah Siap Kerja.

Rumah Siap Kerja is one of the programs done by Prabowo-Sandi as the manifestation of agreements during the campaign period. This stage was the final method of Sales Oriented Party which is included as one of the political marketing communication models by LessMarshment. In addition to the Rumah Siap Kerja program, Kawendra also explained that during the campaign period, Pak Prabowo specifically conveyed the threat that would occur based on the Ghost Fleet novel, Indonesia would disband in 2030, as stated in the following statement:

Sweet promises and threats, um.. we are talking about threats during the presidential election era, not talking about what kind of threats, but rather threats to the condition of the nation. That is what we convey, as it is to the community. Our debt has increased tremendously, right, unemployment is everywhere, the price is high, and imagine maybe um... sometime in the future, as predicted in a Ghost Fleet novel, Indonesia 2030 could be disbanded, right? actually that is not Pak Prabowo's statement but Pak Prabowo conveyed the contents of the novel. So that means they think that foreign countries who made the novel consider Indonesia to be a country that will disappear in a certain year. So that's what Pak Prabowo said, it's actually not a threat but warns the Indonesian people that there are predictions from foreigners through novels so that they don't get sued, right, one strategy is between making novels or making other scientific works. Novels tend to be fictional, right, so there are no lawsuits. Nah.. that foreseen there will be no Indonesia in 2030, this is a danger. Pak Prabowo actually warned, what is his promise, we will open the widest possible job opportunities, just the economy, improve the economy."

Pak Mardani also conveyed the same thing, along with his statement:

"um..Ghost Fleet, right... Mr. Prabowo likes to read, and when interpreted by Ghost Fleet, that Indonesia could disappear in 2030 um.. warning Mr. Prabowo actually reminded of sovereignty, actually he is still in line with um... with um.. sovereignty issue, this is simple if we don't immediately e... lift the nation's sovereignty, yes, the ghost fleet story in 2030 can be realized, Indonesia will disappear from the world map. So, actually, it is still in line with sovereignty, but because of the current era, especially when we are contender, right, the challenger, when um.. the whole narrative is not raised what appears, Mr. Prabowo is currently politic of fear." 
In the neuroscience approach, the campaign activities carried out, as well as the formation of opinions in an easy and short way are indeed targeting this "croc brain". Downstream or downstream generates unnecessary "knowledgeable" information that touches key points. For example: matters related to group discrimination, racism, ethnicity, race, beliefs, noble cultural values that are believed to be true to the religion adopted. This is reinforced by Pak Bambang's statement below:

"Even now I'm sure they have, agency, what, consultants have started using neuroscience, but yes, because we had a gap, we used the lowest level. I don't agree, but it is effective because we were just as rich as we were selling a product, we talked about it, unless we just target the segment above, right? But if we talk about the fate of products, when it comes to politics, it should be like marketing massive products, what everyone wants if that's the case, right. Is that so, massive, following the structure of the social order, so that stupid methods were taken. That's why croc brain used, crocodile brain."

Pak Bambang's statement shows that the campaigns carried out by the candidates can trigger emotions. Emotions drive our behavior; the world is driven by emotions. Capturing mind (through traditional marketing) is one thing, capturing hearts is quite another [30]. This can turn out to be an effective political campaign if it done in the right way. The results of research conducted by Svetlik et al. [14] show that negative political advertising and its effectiveness has always been concern of not only political scientists, but also sociologists and marketing experts. This specific form of advertising is also increasingly used in the Czech political environment.

\section{Conclusions}

The finding revealed that Prabowo-Sandi applied Less-Marshment political marketing communication model, especially the Sales Oriented Party approach consisting of six stages, namely product design, market intelligence, communication, campaign, election dan delivery. The political product offered by Prabowo-Sandi was populist economy which was deemed enable to draw constituent attention, especially in young generation. This product was consistently run start from the beginning until the end campaign period even though they failed on the election.

Based on the findings, it is concluded that the political message as the political product delivered during the campaign period was not done optimally. The message about populist economy which became the main focus of Prabowo-Sandi was not successfully driven to be a strong message for society to remember. For that reason, the team campaign is supposed to focus on the political message or product that will be addressed to each stages in political marketing communication. In addition, based on the results of the study, it was found that political marketing communications carried out by Prabowo-Sandi in the 2019 presidential election campaign used the Neuroscience approach using the triune brained theory. Meanwhile, this research shows that Prabowo-Sandi and their political consultants have stimulated the three sub-systems of the brain.

\section{References}

[1] E. Y. Okan, A. Topcu, and S. Akyüz, "The role of social media in political marketing: 2014 local elections of turkey,” Eur. J. Bus. Manag., vol. 6, no. 22, pp. 131-140, 2014. 
[2] A. Rahman, K. V. U. Subiakto, J. T. Admojo, and F. Hariyati, "Political Marketing Communication in Building Brand Awareness towards Young Voters," Int. J. Commun. Res., vol. 10, no. 3, pp. 286-295, 2020.

[3] M. P. Firmanzah, “Antara Pemahaman dan Realitas,” Jakarta Yayasan Obor Indones., 2012.

[4] Y. Durmaz and E. DirekÃ, "A Theoretical Approach to Political Marketing," Glob. J. Manag. Bus. Res., 2016.

[5] D. Sahputra, I. Muda, T. W. Hidayat, and W. Waridah, "Social Media and Civil Society in the Governor's Election of North Sumatera 2018,” J. Komun. Ikat. Sarj. Komun. Indones., vol. 5, no. 1, pp. 10-17, 2020.

[6] M. Axhami, V. H. Panajoti, M. Mersini, and others, "Factorial Analysis Application in Political Market-Case of Albania," Rom. Econ. Bus. Rev., vol. 10, no. 2, pp. 45-54, 2015.

[7] D. Fadillah, L. Z. Lin, and D. Hao, "Social Media and General Elections in Malaysia 2018 and Indonesia 2019," J. Komun. Ikat. Sarj. Komun. Indones., vol. 4, no. 1, pp. 1-8, 2019.

[8] M. S. Saraswati, "Social media and the political campaign industry in Indonesia," J. Komun. Ikat. Sarj. Komun. Indones., vol. 3, no. 1, pp. 51-65, 2018.

[9] F. Sierra-Caballero, "Cyberactivism and social movements. The Oppositional Public Space in contemporary technopolitics," 2018.

[10] G. Appel, L. Grewal, R. Hadi, and A. T. Stephen, "The future of social media in marketing," J. Acad. Mark. Sci., vol. 48, no. 1, pp. 79-95, 2020

[11] Z. M. Monggilo, "Kajian Literatur Tentang Tipologi Perilaku Berinternet Generasi Muda Indonesia," 2016.

[12] Ó. F. Gonçalves and P. S. Boggio, "Is there a TRUMP brain? Implications for mental health and world peace," Porto Biomed. J., vol. 2, no. 6, pp. 247-249, 2017.

[13] R. Kanai, T. Feilden, C. Firth, and G. Rees, "Political orientations are correlated with brain structure in young adults," Curr. Biol., vol. 21, no. 8, pp. 677-680, 2011.

[14] J. Světl '’ik and others, "Impact of negative political campaigns on the effectiveness of communication (cognition, emotions and voting behavior)," Polit. Prefer., no. 13, pp. 125$138,2016$.

[15] N. HAMELIN, K. MANDREKAR, and T. HARCAR, "Negative Marketing in Political Campaigns and Its Effect on the Voting Decision of the Indian Millennial," Eurasian J. Bus. Econ., vol. 12, no. 23, pp. 1-15, 2019.

[16] H. Blumer, Symbolic interactionism: Perspective and method. Univ of California Press, 1986.

[17] A. Liliweri, "Komunikasi Serba Ada Serba Makna, edisi pertama cetakan ke-1," Kencana Prenada Media Group. Jakarta, 2011.

[18] A. Shama, "The marketing of political candidates," J. Acad. Mark. Sci., vol. 4, no. 4, pp. 764777, 1976.

[19] R. P. Ormrod, S. C. M. Henneberg, and N. J. O'Shaughnessy, Political marketing: Theory and concepts. Sage Publications Limited, 2013.

[20] J. Lees-Marshment, B. Conley, and K. Cosgrove, Political marketing in the United States Routledge, 2014.

[21] T. Ikrar, "Ilmu Neurosains Modern," Yogyakarta: Pustaka Pelajar, 2016.

[22] W. E. Connolly, Neuropolitics: Thinking, culture, speed, vol. 23. U of Minnesota Press, 2002.

[23] P. D. MacLean, The triune brain in evolution: Role in paleocerebral functions. Springer Science \& Business Media, 1990.

[24] H. Cangara, "Pengantar Ilmu Komunikasi Jakarta: Raja Grafindo Persada," 2012.

[25] D. McQuail, "Teori komunikasi massa." Salemba Humanika, 2011.

[26] M. Lister, J. Dovey, S. Giddings, K. Kelly, and I. Grant, New media: A critical introduction. Taylor \& Francis, 2009

[27] A. M. Kaplan and M. Haenlein, "Users of the world, unite! The challenges and opportunities of Social Media," Bus. Horiz., vol. 53, no. 1, pp. 59-68, 2010

[28] F. Sulianta, Keajaiban sosial media. Elex Media Komputindo, 2015.

[29] P. D. Sugiyono, "Metode Penelitian Bisnis: Pendekatan Kuantitatif, Kualitatif, Kombinasi, dan R\&D," Penerbit CV. Alf. Bandung, 2017. 
[30] P. Deshwal, "Emotional Marketing: Sharing the Heart of Consumers," Int. J. Adv. Res. Manag. Soc. Sci., vol. 4, pp. 254-265, 2015. 